\title{
PENGARUH PENERAPAN METODE COOPERATIVE LEARNING MODEL JIGSAW PADA LAYANAN BIMBINGAN KLASIKAL TERHADAP PEMAHAMANSELF REGULATED LEARNING (Studi Eksperimen Pada Siswa Kelas XI Tata Boga 3 SMK Negeri 30 Jakarta)
}

\author{
Kartika Sari ${ }^{1}$ \\ Dra. Endang Setiyowati ${ }^{2}$ \\ Sjenny A. Indrawati, Ed.D ${ }^{3}$
}

\begin{abstract}
Abstrak
Penelitian ini bertujuan untuk melihat pengaruh penerapan metode Cooperative Learning model Jigsaw pada layanan Bimbingan Klasikal terhadap pemahaman Self Regulated Learning pada siswa kelas XI Tata Boga 3 SMK Negeri 30 Jakarta pada bulan Januari-April 2014. Metode penelitian yang digunakan dalam penelitian ini adalah Pre Eksperimental Designs (desain tanpa kelompok kontrol) dengan kelompok One-Group Pre-test-Post-test Design.Sampel dalam penelitian ini berjumlah 28 siswa. Berdasarkan data yang diperoleh, pada hasil pre-test rata-rata skor sebesar 12,29 dan hasil posttest rata-rata skor mengalami peningkatan menjadi 18,89. Hasil uji hipotesis menyatakan bahwa thitung $=4,89>$ ttabel $=1,70$ dengan ttabel pada taraf signifikan $\alpha=5 \%$, yang berarti Ho ditolak dan $\mathrm{H} 1$ diterima sehingga terdapat pengaruh penerapan metode Cooperative Learning model Jigsaw pada layanan Bimbingan Klasikal terhadap pemahaman Self Regulated Learning pada siswa kelas XI Tata Boga 3 SMK Negeri 30 Jakarta. Berdasarkan hasil pre-test dan post-test memperlihatkan peningkatan skor rata-rata, maka siswa dapat memahami mengenai Self Regulated Learning dengan baik.
\end{abstract}

Kata kunci: Cooperative Learning Model Jigsaw, Pemahaman Self Regulated Learning

\section{Pendahuluan}

Belajar merupakan proses interaksi antar indivi$\mathrm{du}$ (peserta didik) dengan lingkungannya yang memungkinkan terjadinya perubahan tingkah laku pada diri individu terjadi karena adanya interaksi antara individu dengan individu lain dan interaksi individu dengan lingkungannya. Di sekolah, siswa diharapkan mampu belajar lebih mandiri, disiplin dalam mengatur waktu, dan melaksanakan kegiatan belajar dengan lebih terarah.Bekal utama yang dibutuhkan siswa agar dapat belajar lebih mandiri dan disiplin dalam mengatur waktu kegiatan belajarnya adalah menyesuaikan diri dengan lingkungannya.

Self Regulated Learning merupakan konsep

1 Mahasiswa Jurusan Bimbingan dan Konseling FIP UNJ, kartikasari13@gmail.com

2 Dosen Bimbingan dan Konseling FIP UNJ,

3 Dosen Bimbingan dan Konseling FIP UNJ, 
mengenai bagaimana seorang siswa menjadi pengatur bagi belajarnya sendiri.Self Regulated Learning merupakansuatu proses dimana seorang siswa mengaktifkan dan mendorong kognisi (cognition), perilaku (behaviours) dan perasaannya (affect) secara sistematis dan berorientasi pada pencapaian tujuan belajar.Penggunaan Self Regulated Learning merupakan pengelolaan aktivitas belajar yang mengarahkan pada strategi pembelajaran diri siswa yang diharapkan siswa mencapai prestasi belajar yang optimal dan dapat merangsang siswa untuk mengembangkan potensi diri.

Penerapan metode belajar yang menarik merupakan inovasi guru untuk mempermudah penyampaian materi kepada siswa agar belajar lebih efektif dan menyenangkan. Salah satu model pembelajaran Cooperative Learning yang akan diberikan dalam penelitian ini adalah Cooperative Learning model Jigsaw. Model Jigsaw ini dikembangkan dengan memberikan penekanan pada keunggulan tutor sebaya, yaitu siswa belajar dari siswa lainnya menggunakan bahasa mereka sendiri, sehingga lebih mudah dipahami oleh lawan biacaranya. Siswa bekerjasama dalam satu tim untuk mengolah informasi dan sekaligus meningkatkan keterampilan dalam berkomunikasi dengan meningkatkan rasa tanggung jawab siswa terhadap pembelajaran orang lain dan siswa juga harus memberikan dan mengajarkan materi tersebut kepada anggota kelompoknya.

Pelayanan Bimbingan Klasikal merupakan peran yang penting dalam pencegahan berbagai permasalahan siswa dalam kegiatan belajar mengajar termasuk membimbing para siswa untuk dapat memiliki pengaturan diri yang lebih baik dalam belajar. Melalui metode Cooperative Learning model Jigsaw pada layanan Bimbingan Klasikal, diupayakan dapat meningkatkan pemahaman siswa ter-hadap Self Regulated Learning. Hal ini dilakukan agar siswa dapat mengatur dan mengarahkan dirinya sendiri sehingga siswa mampu menyesuaikan dan mengendalikan diri, terutama bila menghadapi tugas-tugas yang sulit. Selain itu, bila siswa dapat mengatur perilaku dan mengontrol jalannya proses belajar mereka sendiri maka siswa dapat belajar dengan baik dan memperoleh nilai yang yang memuaskan.

Rumusan masalah "Apakah Terdapat Pengaruh Penerapan Metode Coopertive Learning, Model
Jigsaw Pada Layanan Bimbingan Klasikal Terhadap Pemahaman Self Regulated Learning Siswa Kelas XI Tata Boga 3 SMK Negeri 30 Jakarta?". Tujuan penelitian ini untuk mengetahui pengaruh penerapan metode Jigsaw dalam layanan Bimbingan Klasikal terhadap pemahaman siswa mengenai Self Regulated Learning pada siswa kelas XI Tata Boga 3 SMK Negeri 30 Jakarta.

\section{Kajian Teori \\ Pemahaman (Taksonomi Bloom)}

Pemahaman dalam kognitif berada pada tingkat kedua setelah individu melalui proses mengetahui. Menurut B.S Bloom (Winkel, 1996:246), pemahaman mencakup kemampuan untuk menangkap makna dan arti dari bahan yang dipelajari. Adanya kemampuan ini dinyatakan dalam menguraikan isi pokok dari suatu bacaan; mengubah data yang disajikan dalam bentuk tertentu ke bentuk lain, seperti rumus matematika ke dalam bentuk kata-kata; membuat perkiraan tentang kecenderungan yang nampak dalam data tertentu, seperti dalam grafik. Bloom (Akhmad Sudrajat, 2009:2) juga mengatakan bahwa pemahaman ditunjukkan melalui tiga tingkatan, yaitu :

1. Menerjemahkan (Translation) dapat diartikan bahwa seseorang dapat menguraikan komunkasi ke dalam bahasa lain atau dalam bentuk lain dari komunikasi. Hal ini biasanya melibatkan pemberian makna dalam berbagai bagian dari komunikasi.

2. Menafsirkan (Interpretation) yaitu menjelaskan makna yang terdapat dalam simbol, baik dalam bentuk simbol verbal maupun non verbal. Seseorang dapat dikatakan telah dapat menginterpretasikan tentang suatu konsep atau prinsip tertentu jika dia telah mampumembedakan dan memperbandingkan.

3. Ekstrapolasi (Ekstrapolation) yaitu melihat pembuatan perkiraan atau prediksi seseorang berdasarkan pemahamannya atas kondisi atau kecenderungan yang dijelaskan dalam komunikasi.

\section{Cooperative LearningModel Jigsaw}

Cooperative Learning adalah pembelajaran yang bekerja dalam kelompok, dimana siswa dalam satu kelas dipandang sebagai satu kesatuan kelompok 
itu sendiri dan selanjutnya dibagi ke dalam kelompok kecil. Siswa dalam situasi Cooperative Learning didorong atau dituntut untuk mengerjakan dan menyelesaikan tugas secara bersama-sama.Pelajaran dengan Cooperative Learning (Richard, 2008:5) dapat ditandai oleh aspek-aspek berikut ini :

1. Siswa bekerja dalam tim untuk mencapai tujuan belajar

2. Tim-tim terdiri atas siswa yang bereprestasi rendah, sedang, dan tinggi.

3. Bilamana mungkin, tim-tim terdiri atas campuran ras, budaya, dan gender.

4. Semua reward berorientasi kelompok maupun individu.

Pembelajaran kooperatif model Jigsaw dikembangkan dengan memberikan penekanan pada keunggulan tutor sebaya. Pada tutor sebaya, siswa belajar dari siswa lainnya menggunakan bahasa mereka sendiri sesuai usia mereka, sehingga lebih mudah dipahami oleh lawan biacaranya. Menurut Elliot Aroson dan rekan-rekan sejawatnya Aroson\&Patnoe yang dikutip Richard I. Arends (2008:13), mendefinisikan bahwa menggunakan Jigsaw, siswa ditempatkan ke dalam tim-tim belajar heterogen beranggota lima sampai enam orang. Berikut ini merupakan gambar hubungan antara tim asal dan tim ahli dalam pelaksanaan pembelajaran model Jigsaw (Richard, 2008:14)

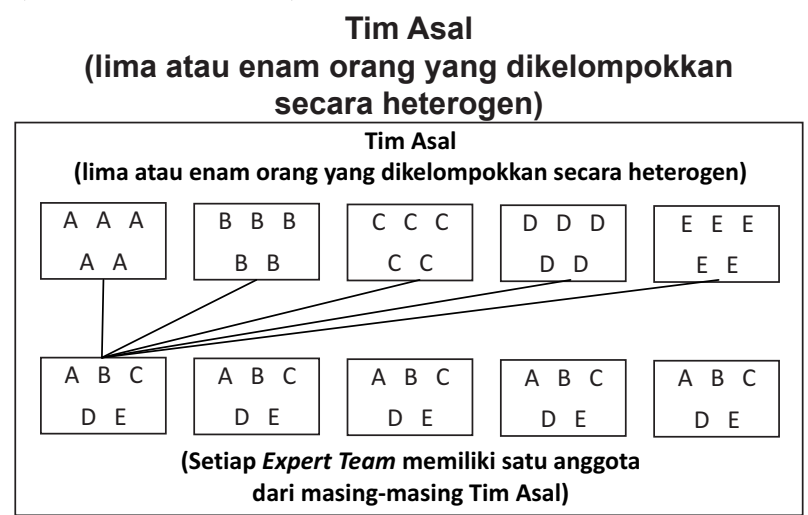

(setiap expert team memiliki satu anggota dari masing-masing tim asal)

\section{Bimbingan Klasikal}

Bimbingan Klasikal (Syamsu dan Juantika, 2009:26) merupakan proses pemberian bantuan bagi peserta didik (siswa) melalui kegiatan-kegiatan se- cara klasikal yang disajikan secara sistematis, dalam rangka membantu siswa mengembangkan potensinya secara optimal. Pelayanan ini memiliki tujuan yang dapat dirumuskan sebagai upaya untuk membantu konseli agar:

1. Memiliki kesadaran dan pemahaman tentang diri sendiri dan lingkungannya (pendidikan, pekerjaan, sosial budaya dan agama).

2. Mampu mengembangkan keterampilan untuk mengidentifikasi tanggung jawab atau tingkah laku yang layak bagi penyesuaian diri dengan lingkungannya.

3. Mampu menangani atau memenuhi kebutuhan dan masalahnya.

4. Mampu mengembangkan dirinya dalam rangka mencapai hidupnya.

\section{Self Regulated Learning}

Self Regulated Learning (Zimmerman,1989:329 )secara umum, para siswa dapat digambarkan pada tingkat pengaturan diri metakognitif, motivasi, dan partisipasi perilaku aktif dalam proses belajar mereka sendiri. Pengaturan diri dalam belajar ini adalah tingkat peran aktif siswa dalam mengarahkan proses pembelajaran metakognitif, motivasi dan perilakunya. Metakognitif yang dimaksud oleh Zimmerman adalah proses-proses pengambilan keputusan yang mengatur pemilihan dan penggunaan berbagai bentuk pengetahuan. Struktur wawancara yang digunakan oleh Zimmerman dan Martinez Pons (1986:618) untuk mengukur strategi yang digunakan siswa dalam belajar adalah sebagai berikut :

\section{Evaluasi Diri (Self Evaluating)}

Inisiatif siswa untuk mengevaluasi kualitas atau kemajuan pekerjaan mereka.Dalam hal ini, evaluasi diri merupakan evaluasi hasil kerja yang telah didapat serta pencapaian pemahaman mereka tentang materi bahasan.

2. Mengorganisani dan Transformasi (Organizing and Transforming)

Inisiatif siswa mengatur kembali materi pelajaran untuk mempermudah proses belajar sehingga dapat meningkatkan hasil belajar siswa.

3. Menentukan Tujuan dan Merencanakan (Goal Setting and Planning)

Inisiatif siswa untuk menentukan tujuan atau sub 
tujuan akademis dan merencanakan urutan, waktu, penyelesaian aktifitas-aktifitas yang berkaitan dengan tujuan tersebut.

4. Mencari Informasi (Seeking Information)

Inisiatif siswa untuk mencari informasi di luar nara sumber ketika mengerjakan tugas.

5. Menyimpan Catatan dan Pemantauan (Keeping Records and Monitoring)

Inisiatif siswa dalam mencatat hal-hal penting yang berhubungan dengan peristiwa-peristiwa atau hasil belajar.

6. Strukturisasi Lingkungan (Environmental structuring)

Inisiatif siswa untuk mengukur tempat/lingkungan yang mendukung mereka di dalam kegiatan belajar, sehingga belajar menjadi lebih mudah.

7. Konsekuensi Diri (Self Consequences) Inisiatif siswa yang dapat mengatur diri atau membayangkan tentang hadiah atau hukuman keberhasilan atau kegagalannya.

8. Berlatih dan Mengingat Kembali (Rehearsing and Memorizing)

Inisiatif siswa mengingat kembali materi pelajaran dengan latihan-latihan untuk meningkatkan kemampuan memahami suatu materi pelajaran.

9. - 11) Mencari Bantuan Sosial (Seeking Social Assistance)

Inisiatif siswa untuk memperoleh bantuan mengenai materi-materi pelajaran melalui:

(9) Bantuan teman sebaya (seek peer assistance); bila menghadapi masalah dengan tugas yang sedang dikerjakan, siswa meminta bantuan teman sebaya.

(10) Bantuan guru (seek teacher assistance); bertanya kepada guru di dalam maupun di luar lingkungan belajar bila ada materi yang tidak dimengerti.

(11)Bantuan orang dewasa (seek adult assistance); meminta bantuan orang dewasa yang berada di dalam dan di luar lingkungan bila ada materi yang tidak dimengerti.

12 - 14) Meninjau Kembali Catatan (Reviewing Records)

(12)Meninjau catatan (review notes) sebelum mengikuti ujian, siswa meninjau ulang catatan sehingga memahami topik yang diujikan.

(13)Meninjau soal ujian (review test); menjadikan soal-soal ujian terdahulu tentang topik- topik tertentu dan tugas-tugas yang telah dilakukan sebagai sumber informasi untuk belajar.

(14)Meninjau teks (review textbooks); membaca textbooks merupakan sumber informasi yang dijadikan penunjang catatan sebagai sarana belajar.

15.Lain-Lain (Others)

Perilaku belajar yang dipengaruhi oleh orang lain, seperti guru atau orang tua, dan semua respon verbal yang tidak biasa.

\section{Metode Penelitian}

Penelitian ini dilakukan pada 28 siswa kelas XI Tata Boga 3 SMK Negeri 30 Jakarta.Penelitian ini dilakukan pada bulan Januari-April 2014. Penelitian ini dilakukan delapan kali pertemuan kegiatan Bimbingan Klasikal dengan pemberian pre-test dan post-test. Kegiatan dilakukan di SMK Negeri 30 Jakarta di ruang Ruang Teori (RT) 3.

Metode yang digunakan dalam penelitian ini adalah eksperimen dengan pre experiment design. Teknik sampling yang digunakan adalah sampling incidental karena melihat masalah yang ditemui peneliti hanya terdapat pada kelas XI Tata Boga 3 yang akan menjadi subjek penelitian ini. Mengukur pemahaman siswa dalam penelitian ini menggunakan alat tes berupa soal multiple choice untuk melihat perbedaan data pre-test dan post-tes. Setelah dilakukan uji coba instrumen pada 28 responden didapat 36 item yang valid dan 36 item yang drop. Sedangkan berdasarkan rumus Kuder Richadson number 20 (KR-20)didapat nilai reliabilitas sebesar 0,877 .

Analisis data dalam penelitian ini menggunakan analisis deskripstif kuantitatif.Analisis ini digunakan untuk memberikan gambaran mengenai data dalam bentuk prosentase. Penyajian data dilakukan dengan mencari mean atau rerata dan ukuran sentral (simpangan baku dan varians). Pengujian hipotesis merupakan tahap akhir yang dilakukan dengan menggunakan teknik perhitungan t-test atau Uji-t.

\section{Hasil dan Pembahasan}

Hasil dari penelitian ini, diperoleh rata-rata pemahaman sebelum diberikan perlakuan sebesar 12,29 dan setelah diberikan perlakuan menjadi 
18,89. Perubahan pada hasil setelah diberikan perlakuan menunjukkan adanya peningkatan skor rata-rata para siswa. Hasil peningkatan skor yang diperoleh dari 28 siswa, menunjukkan adanya peningkatan pemahaman Self Regulated Learning sebelum dan sesudah perlakuan.Data yang didapat terbagi dalam tiga kategori yaitu tinggi, sedang dan rendah. Agar mempermudah, hasil data akan dideskripsikan dalam penggambaran histogram sebagai berikut :

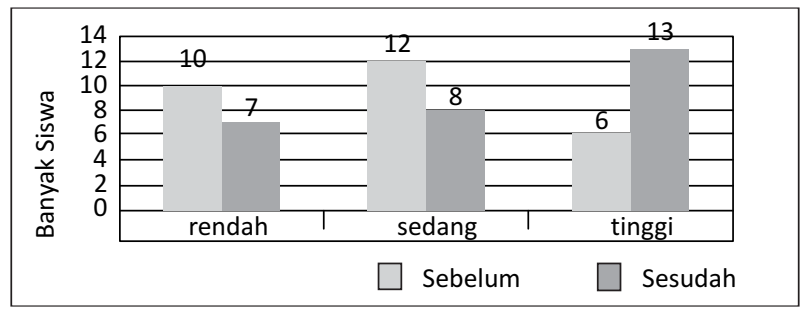

Gambar Histogram Kategori Self Regulated Learning

Siswa yang berada dalam kategori tinggi dengan skor di atas rata-rata menunjukkan bahwa siswa dapat memahami dan menganalisis materi yang diberikan dengan baik selama perlakuan berlangsung.Kategori sedang menunjukkan bahwa siswa memahami dan mampu mengaplikasikan dengan baik materi yang diberikan selama perlakukan.Sedangkan siswa yang berada dalam kategori rendah dapat diartikan bahwa siswa masih belum mampu memahami, tetapi siswa mampu mengetahui materi yang diberikan dengan baik selama kegiatan berlangsung.

Meningkatnya pemahaman siswa mengenai Self Regulated Learning terlihat juga dari hasil skor setiap indikator yang diberikan oleh siswa dalam melakukan pre-test dan post-test. Agar mempermudah, peningkatan skor pre-test dan post-test setiap indikatornya dapat dideskripsikan dalam tabel sebagai berikut :

Tabel

Peningkatan Skor Pre-Test dan Post-Test Setiap Indikator

Peningkatan Skor Pre-Test dan Post-Test Setiap Indikator

\begin{tabular}{|c|l|c|c|c|}
\hline \multirow{2}{*}{ No } & \multirow{2}{*}{ Indikator } & \multicolumn{2}{|c|}{ Skor } & Pening- \\
\cline { 3 - 4 } & & Pre-Test & Post-Test & $\begin{array}{c}\text { Patan } \\
\text { Skor }\end{array}$ \\
\hline 1 & Mengartikan & 57 & 93 & 36 \\
\hline 2 & Memberi Contoh & 68 & 87 & 19 \\
\hline 3 & Membedakan & 59 & 88 & 29 \\
\hline 4 & Menyimpulkan & 44 & 88 & 44 \\
\hline 5 & Memprediksi & 57 & 88 & 31 \\
\hline 6 & Memfaktorkan & 59 & 85 & 26 \\
\hline
\end{tabular}

Tabel ini menunjukkan adanya selisih antara skor post-test dan pre-test setiap indikator yang ada pada intrumen Self Regulated Learning.Terlihat bahwa setiap indikator mengalami peningkatan pada akhir kegiatan yang dilakukan.Pada hasil pre-test dapat dilihat bahwa indikator tertinggi berada pada indikator memberi contoh dan yang terendah pada indikator menyimpulkan. Hasil ini menunjukkan bahwa pada indikator tertinggi, siswa sudah mampu menguraikan komunikasi ke dalam bahasa lain. Hal ini dapat diartikan bahwa siswa sudah mampu menganalisis soal yang diberikan dengan baik.Pada indikator yang rendah, siswa belum mampu untuk menjelaskan makna yang terdapat dalam simbol, baik dalam bentuk simbol verbal maupun non verbal.Hal ini dapat diartikan bahwa siswa belum dapat mengaplikasikan soal dengan baik.

Indikator tertinggi pada hasil post-test berada pada indikator mengartikan dan yang terendah berada indikator memfaktorkan. Pada indikator tertinggi dapat diartikan bahwa siswa mampu menganalisis soal yang diberikan dengan menguraikannya ke dalam bahasa lain atau bentuk lain dari komunikasi. Pada indikator yang rendah, siswa belum mampu untuk memperkirakan atau memprediksi pemahamannya, sehingga siswa dapat dikatakan belum mampu menganalisis tetapi sudah mampu untuk memahami isi soal yang diberikan.Pada hasil posttest terdapat skor indikator yang sama yang dapat diartikan bahwa para siswa sudah mampu menjelaskan makna yang terdapat dalam simbol dan melihat pembuatan perkiraan berdasarkan pemahamannya. Hal ini menunjukkan bahwa siswa sudah mampu memahami dan mengaplikasikan soal yang diberikan dengan menguraikan komunikasi ke dalam bahasa lain dengan baik.

Berdasarkan paparan sebelumnya, dapat dilihat bahwa model Jigsaw dapat mempengaruhi pemahaman siswa mengenai Self Regulated Learning. Pembelajaran model jigsaw ini dapat dijadikan informasi serta memberikan pemahaman kepada siswa mengenai suatu konsep atau materi. Hasil penelitian ini membuktikan bahwa terdapat pengaruh metode Cooperative Learning model Jigsaw pada layanan Bimbingan Klasikal terhadap pemahaman siswa mengenai Self Regulated Learning. 


\section{Kesimpulan dan Saran \\ Kesimpulan}

Berdasarkan hasil data yang diperoleh, terdapat peningkatan pemahaman siswa mengenai Self Regulated Learning antara sebelum dan sesudah diberikan perlakuan. Sebelum perlakuan, pemahaman siswa berada skor rata-rata sebesar 12,29. Setelah diberikan perlakuan berupa metode Cooperative Learning model Jigsaw, pemahaman siswa mengalami peningkatan sebanyak 6,60 sehingga skor ratarata menjadi 18,89. Pengujian hipotesis penelitian dilakukan dengan menggunakan uji-t. Hasil yang diperoleh berupa nilai t hitung sebesar 4,89 dan t tabel sebesar 1,70. Selanjutnya, dengan membandingkan nilai thitung dan ttabel, maka diperoleh hasil thitung $=4,89>\mathrm{t}$ tabel $=1,70$. Melihat perbandingan ini maka dapat disimpulkan bahwa $\mathrm{H0}$ ditolak dan H1 diterima. Berdasarkan pengujian hipotesis tersebut, dapat disimpulkan bahwa terdapat pengaruh yang signifikan pada metode Cooperative Learning model Jigsaw pada layanan Bimbingan Klasikal terhadap pemahaman siswa mengenai Self Regulated Learning pada kelas XI Tata Boga 3 SMK Negeri 30 Jakarta.

\section{Saran}

Saran yang dapat diberikan berdasarkan hasil penelitian ini bagi pihak-pihak terkait yaitu:

1. Bagi pihak sekolah, diharapkan :

a. Memberikan perhatian dan dukungan lebih lagi terhadap pelaksanaan layanan Bimbingan dan Konseling, khususnya terhadap pelaksanaan pengembangan metode pengajaran dalam layanan Bimbingan Klasikal yaitu dengan menyiapkan sarana dan prasarana yang memadai di sekolah.

b. Memnyediakan jam Bimbingan dan Konseling satu jam, dua kali setiap minggunya pada seluruh siswa guna mengoptimalkan pemberian layanan bimbingan klasikal di sekolah.

c. Mengembangkan pemahaman siswa mengenai Self Regulated Learning ini melalui layanan Bimbingan Klasikal lebih optimal sehingga dapat menunjang hasil belajar yang lebih maksimal.
2. Bagi guru Bimbingan dan Konseling, diharapkan:

a. Menindak lanjuti hasil penelitian ini tentang Self Regulated Learning agar dapat dijadikan materi untuk layanan Bimbingan Klasikal dan untuk kegiatan konseling individu agar siswa melakukan tahapan Self Regulated Learning yang telah dipahami oleh para siswa.

b. Mengoptimalkan pemberian layanan Bimbingan Kasikal dengan menggunakan metode Cooperative Learning model lainnya seperti Student Teams Achievement Divisions (STAD), Group Investigation (GI) dan pendekatan structural,yang lebih menyenangkan dan lebih efektif untuk meningkatkan pemahaman suatu materi tertentu dan menggunakan kegiatan yang bervariasi seperti games (permainan)yang sesuai dengan materi untuk meningkatkan semangat keakraban antar siswa dengan fasilitatornya, khususnya Guru Bimbingan dan Konseling.

3. Bagi siswa disarankan agar dapat menerapkan Self Regulated Learning dalam kegiatan belajar di sekolah maupun di rumah. Hal ini dilakukan agar siswa dapat meningkatkan prestasi belajar, mandiri dan bertanggung jawab atas tugas-tugas akademis yang diberikan.

4. Bagi peneliti lain, yang ingin melakukan tindak lanjut atau ingin melaksanakan penelitian seperti ini, disarankan:

a. Membuat instrumen penelitian perlu diperhatikan lebih baik. Hal ini dilakukan agar tujuan dari suatu pengukuran dapat tercapai dengan baik.

b. Mengembangkan penelitian dengan menggunakan metode Cooperative Learning model Jigsaw dalam desain yang berbeda, yaitu terdapat kelompok kontrol untuk mengontrol variabel lain yang dapat mempengaruhi hasil penelitian sehingga penelitian akan lebih baik dan bersih. 


\section{Daftar Pustaka}

Arends, Richard I. 2008. Learning To Teach 2 "Belajar Untuk Mengajar”. Yogyakarta: PT. Pustaka Pelajar.

Sudrajat, Akhmad. Taksonomi Tingkah laku Individu. 2009. (http://akhmadsudrajat.wordpress. com/2008/01/30/taksonomi-perilaku-individu/). Diunduh tanggal 5 April 2013, pukul 10.30.

Winkel, W.S. 1996. Psikologi Pengajaran. Jakarta: Gramedia.

Yusuf, Syamsu \& Juntika Nurhisan. 2009. Landasan Bimbingan dan Konseling.Bandung: PT Remaja Rosdakarya.
Zimmerman, BJ. 1989. A Social Cognitive View of SelfRegulated Academic Learning, Journal of Educational Psychology. new York: American psychological Association inc.

Zimmerman, BJ and Manuel Mantinez Pons. 1986. Development of a Structured Interview For Assessing Student Use of Self-Regulated Learning Strategies, American Educational Research Journal, Vol. 23, No. 4. American Educational Research Association: City University of New York. 